Kok M., H. Massinen, I. Moshnikov, E. Penttilä, S. Tavi \& L. Tuomainen (toim.) 2019. Pidetään kielet elävinä - Keeping languages alive - Piemmö kielet elävinny. AFinLAn vuosikirja 2019. Suomen soveltavan kielitieteen yhdistyksen julkaisuja n:o 77. Jyväskylä. s. i-xvi.

\author{
Maria Kok, Henna Massinen, Ilja Moshnikov, Esa Penttilä, Susanna \\ Tavi \& Laura Tuomainen \\ Itä-Suomen yliopisto
}

\title{
Monimuotoinen kielimaisema ja kielellinen hyvinvointi
}

\begin{abstract}
This introduction article discusses language vitality and language diversity in connection with linguistic well-being, which were the main ideas reflected behind the theme of the AFinLA Autumn Symposium 2018, "Keeping languages alive". Linguistic well-being is a new concept that addresses the issues related to language policy and linguistic practices within a speech community and how these impact the individual members of that community. Among the main factors behind linguistic well-being we find linguistic human rights, which emphasize, for example, the right for anyone to identify with one or more languages without being discriminated and the right for basic education in one's own language. These rights are particularly linked to how endangered and minority languages are treated in the society and they can be actively promoted by language policy and education. However, linguistic wellbeing is not just a matter of minorities but it affects the whole community. The more diverse the language environment and linguistic landscape of a speech community is, the healthier and more affluent the whole community is - both its minority and majority language speakers.
\end{abstract}

Keywords: linguistic well-being, language diversity, linguistic human rights, multilingualism Asiasanat: kielellinen hyvinvointi, kielellinen monimuotoisuus, kielelliset ihmisoikeudet, monikielisyys 


\section{Johdanto}

AFinLAn syyssymposium 2018 kokosi yhteen suuren joukon kielentutkijoita, ja tapahtumassa pidettiin yli 70 esitelmää. Niistä merkittävä osa liittyi tavalla tai toisella konferenssin teemaan, joka oli Pidetään kielet elävinä. Teema heijastelee järjestävän yliopiston tutkimusprofilia, sillä Itä-Suomen yliopistossa toimii mm. Karjalan tutkimuslaitos, ja useat filosofisen tiedekunnan ohjelmat ja hankkeet liittyvät Suomen ja Venäjän väliseen raja-alueeseen ja alueella puhuttaviin vähemmistökieliin sekä monikielisyteen ja kielikontakteihin yleisesti.

Esimerkkeinä tällaisista viime vuosina toimineista hankkeista ovat kielikontakteja kontaktilingvistiikan, toisen kielen omaksumisen ja käännöstieteen näkökulmista tarkastellut CROSSLING-hanke, jonka puitteissa syntyi laaja poikkitieteellinen verkosto eri suuntausten tutkijoita (ks. esim. Riionheimo \& Frick 2013; Riionheimo ym. 2014; Paulasto ym. 2014; Riionheimo 2015), ei-ammatillista kääntämistä ja tulkkausta kielikontaktien ja vähemmistökielten elvyttämisen näkökulmasta tutkinut Kontu-hanke (ks. esim. Kolehmainen ym. 2015; Kolehmainen ym. 2016) sekä erityisesti karjalan kielen elvyttämiseen kääntämisen näkökulmasta paneutunut Kiännä-hanke (ks. esim. Kuusi ym. 2017). Hiljattain päättyneessä Vertaileva karjalan kielioppi -hankkeessa (Novak ym. 2019) on kartoitettu karjalan kielen eri murteiden sekä lyydin äänteellisiä ja muodollisia piirteitä ja niiden variaatiota kieliopillisten kuvausten pohjalta. Parasta aikaa on meneillään tutkimushanke Migration and linguistic diversification: Karelian in Tver and Finland (KATVE).

Vuoden 2018 symposiumin tarkoituksena oli tarjota laaja ja monipuolinen näkymä monikielisyyteen, kielten oikeuksiin ja erityisesti kaikkien kielten puhujien, sekä pienten että suurten, kielelliseen hyvinvointiin. Erityisesti halusimme nostaa esille variaation ja kielellisen diversiteetin merkityksen. Jos tavoitteena on esimerkiksi luoda uhanalaiselle kielimuodolle standardoitu kirjakieli, on ratkaistavana monia periaatteellisia kysymyksiä. Tulisiko kirjakielen pohjaksi valita yksi vai useampi murre, ja mikä niistä? Tulisiko kielen eri päämurteille luoda jopa omat kirjakielensä, ja jos tulisi, kuinka monta kirjakieltä kaikkiaan tarvittaisiin? Kenellä tulisi olla valta päättää asiasta, ja kuinka pitäisi suhtautua kielelliseen variaatioon? Valmiita ja yksiselitteisiä vastauksia näihin kysymyksiin ei ole, mutta symposiumin yhtenä tarkoituksena oli tarjota työkaluja myös tällaisten kysymysten pohtimiseen.

Määrittelemme seuraavaksi, luvussa 2, kielellisen hyvinvoinnin käsitteen ja pohdimme sen suhdetta kielten monimuotoisuuteen, kielellisiin ihmisoikeuksiin, kielimaisemaan ja kieliympäristöön. Esittelemme sitten luvussa 3 vuosikirjan 2019 kahdeksan artikkelia, jotka on kirjoitettu symposium-esitelmien pohjalta ja jotka kukin omalla tavallaan liittyvät kielellisen hyvinvoinnin teemaan. 


\section{Mitä on kielellinen hyvinvointi?}

Kielellinen hyvinvointi on käsitteenä vielä tuore, ja siihen liittyvää tutkimusta on tehty varsin niukasti. On oikeastaan vasta herätty kysymään, mitä kielellinen hyvinvointi on tai voisi olla (ks. Paulasto 2018). Kotimaisten kielten keskuksen toiminta- ja taloussuunnitelmassa 2015-2018 kielellinen hyvinvointi kuitenkin mainitaan ihmisen sosiaalisen hyvinvoinnin osatekijänä:

Yhteiskunnan toimivuuden ja yksilön tasapainoisen elämän kannalta on olennaista, että jokaista ihmistä kannustetaan käyttämään omaa äidinkieltään ja että jokaisella on tieto kieleen liittyvistä oikeuksista eri tilanteissa. Jokaiselle yksilölle on myös tärkeää ymmärtää mahdollisimman hyvin maan valtakieltä, jotta voi elää täysivaltaisena yhteiskunnan jäsenenä. (Kotus 2015-2018: 4)

Voinemme tämän perusteella määritellä kielellisen hyvinvoinnin psykososiaaliseksi hyvinvoinnin lajiksi, jonka lähteenä on kieli ja kieleen liittyvät hyvät käytänteet yhteisöissä ja koko yhteiskunnassa. Kielellistä hyvinvointia voidaan edelleen tarkastella yksilön ja yhteisön näkökulmasta. Yksilön ja yhteisön hyvinvointi eivät kuitenkaan ole erillisiä vaan yhteydessä toisiinsa: mikään yhteisö ei voi hyvin, jos sen jäsenet eivät voi hyvin. Yksilötasolla kielellinen hyvinvointi liittyy kiinteästi puhujan oikeuksiin ja mahdollisuuksiin yhteiskunnan ja kieliyhteisön jäsenenä. Yhteisötasolla se merkitsee ennen muuta tervettä ja monimuotoista kielimaisemaa sekä ympäristöjä, jotka tukevat yksilöiden kielellistä hyvinvointia ja suovat kaikille kielille mahdollisuudet kukoistaa (ks. Nettle \& Romaine 2000: 24).

Paulasto (2018) tuo esille myös taiteen kielellisen hyvinvoinnin lähteenä: kielet liittyvät paitsi työhön, koulutukseen ja arkeen myös vapaa-aikaan ja kulttuuriin. Jopa kielten oppimisella voi olla elämyksellinen puolensa, sillä kieliä ei opiskella yksinomaan hyötynäkökohtia silmällä pitäen. Parhaimmillaan uuden kielen oppiminen on voimaannuttava kokemus. Lisäksi kieli on yhteydessä terveyteen. (Paulasto 2018.) Turun yliopiston Kieli-ja käännöstieteiden laitokselle onkin elokuussa 2018 perustettu Kielen ja hyvinvoinnin tutkimuskeskus LaWe, jossa tutkitaan kielen, terveyden ja hyvinvoinnin välisiä kytköksiä (Luodonpää-Manni \& Paananen 2018). Keskuksen tutkimusintresseihin kuuluu mm. hoitotilanteiden kieli ja vuorovaikutus (Paananen 2018, 2019; Paananen \& Majlesi 2018) sekä muistisairaiden kieli (Lindholm \& Wide 2019a, 2019b). Valmisteilla oleva Kieli, hyvinvointi ja sosiaalinen osallisuus (Lindeman ym. tulossa) tarkentanee ilmestyessään kielellisen hyvinvoinnin käsitettä ja määritelmää.

Kielellisen hyvinvoinnin tärkeimpiä tekijöitä ovat kielelliset ihmisoikeudet. Yleisten ihmisoikeuksien tapaan ne ovat perustavanlaatuisia, kaikille ihmisille kuuluvia oikeuksia, joita eivät sen paremmin valtiot kuin yksityiset henkilötkään saa loukata (Skutnabb-Kangas 2012a: 237). Tästä huolimatta niitä voidaan pitää vähiten huomiota saaneena ihmisoikeuksien osa-alueena (Skutnabb-Kangas 2000: 482). 
Kielellisiä inmisoikeuksia ovat mm. oikeus samaistua yhteen tai useampaan kieleen joutumatta diskriminoinnin kohteeksi, oikeus perusopetukseen omalla kielellä, oikeus käyttää omaa kieltään viranomaisten kanssa asioidessa sekä oikeus oppia sen maan virallinen enemmistökieli, jossa asuu (Skutnabb-Kangas 2012a:238). Kielellisten ihmisoikeuksien yhteydessä on tarpeen korostaa erityisesti uhanalaisten ja muiden vähemmistökielten sekä niiden puhujien asemaa (ks. esim. Skutnabb-Kangas 2012a; Piller 2016; Fleisch 2018). Nämä oikeudet koskevat kaikkia, myös enemmistökielten puhujia, mutta heille ne tulevat usein ikään kuin annettuna (Skutnabb-Kangas 2012a: 238). Sen sijaan uhanalaisten ja muiden vähemmistökielten kohdalla kielelliset ihmisoikeudet eivät aina toteudu, mikä puolestaan on usein kielten uhanalaisuuden syynä. Vähemmistöt ovatkin joutuneet vaatimaan oikeuksiaan. (Lindgren 2001: 240; Skutnabb-Kangas 2012a: 238.) Niiden toteutumista voi pitää minimivaatimuksena sekä yksilö- että yhteisötason kielelliselle hyvinvoinnille.

On ensiarvoisen tärkeää, että vähemmistökielten oikeudet turvataan ja että kielienemmistöt tukevat niitä kieliä, joiden asema on uhattuna. Monimuotoinen kieliympäristö on kuitenkin kaikkien etu. Monikielisyydestä on useiden tutkimusten mukaan (ks. esim. Dufva \& Pietikäinen 2009) havaittu olevan myönteistä vaikutusta lapsen kielelliselle kehitykselle ja kognitiivisille taidoille, ja jopa ihmisen aivoille monikielisyys on todettu hyödylliseksi. Vastaavanlaista hyötyä on havaittu olevan myös altistumisesta saman kielen eri murteille (ks. esim. Antoniou ym 2016). Bak ja Mehmedbegovic (2017) vertaavatkin monikielistä ympäristöä terveelliseen ruokavalioon ja ehdottavat päättäjille useita toimenpiteitä kansalaisten "kieliruokavalion" parantamiseksi. Heidän mukaansa kaikkialla yhteiskunnassa olisi lopetettava väärinkäsitysten levittäminen monikielisyyden kuvitelluista haitoista. Sen sijaan tulisi pitää esillä uusinta tutkimustietoa monikielisyyden eduista. Kouluihin ja varhaiskasvatukseen tulisi luoda rakenteita ja toimintamalleja, jotka edistävät kaikkien lasten mahdollisuuksia käyttää ja opiskella vieraita kieliä runsaasti ja monipuolisesti. Myös muissa yhteiskunnan rakenteissa, esimerkiksi vanhusten hoidossa, terveellistä "kieliruokavaliota" tulisi edistää. Vanhuksia tulisi rohkaista käyttämään aktiivisesti kaikkia tuntemiaan kieliä, ja myös uusien kielten opiskeluun tulisi antaa mahdollisuus. (Bak \& Mehmedbegovic 2017: 5-6.)

Nettle ja Romaine (2000) rinnastavat puolestaan kielellisen diversiteetin biodiversiteettiin eli luonnon ja eliölajien moninaisuuteen. Heidän mukaansa meidän päivinämme uhkaavaa kielikatoa voi sekä määrällisesti että laadullisesti verrata siihen massiiviseen eliölajien sukupuuttoaaltoon, joka parhaillaan on käynnissä. Kielten moninaisuutta uhkaavia tekijöitä voi myös verrata eliölajeihin kohdistuviin uhkiin, joista räikein on suoranainen vaino tai hävittäminen. Samoin kuin monia eliölajeja ja niiden elinympäristöjä on systemaattisesti hävitetty, myös moniin vähemmistökieliin ja ennen kaikkea niiden puhujiin on kohdistettu - ja kohdistetaan edelleen - järjestelmällistä sortoa (ks. esim. Nettle \& Romaine 2000: 31-32, 51-52, 96-97; Sarhimaa 2017). Onkin puhuttu suorainaisesta kielellisestä imperialismista, 
jossa suositaan valtakieltä vähemmistökielten kustannuksella ja luodaan samalla kielenkäyttöön pohjautuvaa rakenteellista yhteiskunnallista epätasa-arvoa (Phillipson 2012). Sen seurauksena tapahtuva kielten sammuminen ja kielellisen monimuotoisuuden kato aiheuttavat samankaltaista vahinkoa inmiskunnalle kuin eliölajien sukupuuttoon kuoleminen aiheuttaa luonnon monimuotoisuudelle (Nettle \& Romaine 2000: 125-127). Nettle ja Romaine (2000: 37, 42-43, 58-60, 328-329) eivät pidäkään biodiversiteetin ja kielellisen diversiteetin katoa erillisinä ilmiöinä vaan katsovat, että kysymys on pohjimmiltaan samasta asiasta: vaikka kielet eivät ole eliölajeja, ne ovat kuitenkin osa sitä elämän monimuotoisuutta, joka nyt on uhattuna.

Erityisen salakavala uhka kaikelle monimuotoisuudelle ovat monotypiat eli ympäristöt, jollaisia biodiversiteetin näkökulmasta ovat esimerkiksi suuret, vain yhtä lajia suosivat peltoviljelmät ja plantaasit (ks. esim. Nettle \& Romaine 2006: 265, 268-269; Meijaard ym. 2017; WWF 2018: 26-28, 37-38). Kielellisinä monotypioina voidaan pitää yhteisöjä ja ympäristöjä, joissa suositaan yhtä ainoaa tai muutamaa harvaa kielimuotoa. Monotypioiden suosimisen taustalla on usein hyötyajattelu: samaan tapaan kuin yhden lajin viljelmiä pidetään tehokkaina ja tuottavina, myös yksikielisiä yhteisöjä on totuttu pitämään tehokkaampina kuin sellaisia, joissa esiintyy paljon kielellistä variaatiota (Nettle \& Romaine 2000: 257). Kuten Calvet (2006: 3-5) toteaa, eri kielillä on reaalimaailmassa erilainen markkina-arvo: mitä enemmän käytännöllisiä ja aineellisia etuja tietyn kielen käyttämisen ajatellaan tuottavan, sen suuremmaksi sen markkina-arvo nousee ja sitä enemmän sitä suositaan. Korkean markkina-arvon kielille avautuu uusia käyttöaloja, joten niitä halutaan myös opiskella enemmän. Näin niiden puhujamäärä kasvaa entisestään, mikä puolestaan lisää niiden markkina-arvoa. (Calvet 2006: 3-5; ks. myös Nettle \& Romaine 2000: 65-66, 215-217.) Jos tässä markkina-arvon kasvukierteessä ei ymmärretä samalla huolehtia vähemmistökielistä ja kielellisen monimuotoisuuden säilymisestä, tuloksena on helposti kielellisesti monotyyppinen koulu, yhteisö tai yhteiskunta. Osuva ja ajankohtainen esimerkki kehityksestä, joka lopulta voi johtaa kielelliseen monotypiaan, on englannin ylivalta vieraana kielenä: vaikka englanti on lingua francana erittäin hyödyllinen ja kielenä aivan yhtä arvokas kuin mikä tahansa kieli, sen yksipuolinen suosiminen muiden kielten kustannuksella voi johtaa kielimaiseman ja kielivarannon köyhtymiseen (ks. esim. Nettle \& Romaine 2000: 246; Phillipson \& Skutnabb-Kangas 2013; Pyykkö 2017).

Kielimaiseman käsitettä on tutkimuskirjallisuudessa lähestytty eri tavoin (ks. Gorter 2006). Ehkä yleisimmin kielimaisema-termillä viitataan julkisessa tilassa näkyvään kirjoitettuun kieleen, joka havainnollistuu mm. tienviitoissa, mainostauluissa, kadunnimissä ja kauppojen tai virastojen opasteissa (Landry \& Bourhis 1997: 25). Kielimaisemaa tällä tavoin ymmärrettynä on tutkittu erityisesti kaupunkiympäristöissä (ks. esim. Shohamy ym. 2010), mutta aihetta on lähestytty myös vähemmistökielten näkökulmaa korostaen (k.s esim. Cenoz \& Gorter 
2006; Gorter ym. 2012). Ivkovic ja Lotherington (2009) kytkevät keskusteluun verkkoympäristön visuaaliset tekstit käsitteellään virtuaalinen kielimaisema, ja myös tätä todellisuutta on tutkittu vähemmistökielten näkökulmasta (Moshnikov 2016). Toisaalta kielimaiseman käsitettä on käytetty myös laajemmassa mielessä viittaamaan siihen puhuttuun ja kirjoitettuun kielelliseen ympäristöön, joka erityisesti monikelisessä yhteisössä esimerkiksi tietyllä maantieteellisellä alueella voidaan havaita (Kreslins 2003). Tämä on lähinnä se merkitys, johon kielimaisemalla tässä artikkelissa viitataan.

Myös kieliympäristön käsitteellä on erilaisia määritelmiä ja sovelluksia eri tieteenaloilla. Kieliympäristöllä voidaan tarkoittaa esimerkiksi yhteiskunnan osa-alueita kuten kouluja ja muita oppimisympäristöjä ja tarkastella, kuinka tällainen ympäristö ja siinä käytetyt kielet toimivat äidinkielen tai vieraiden kielten oppimisen kannalta (ks. esim. Cruz-Ferreira 2006; Himmele \& Himmele 2009). Tässä merkityksessä käytämme kieliympäristö-termiä myös tässä artikkelissa ja tarkastelemme, kuinka kieliympäristö vaikuttaa hyvinvointiin. Kieliympäristön ja kielimaiseman käsitteet limittyvät kuitenkin keskenään, joten tietty valtio, paikkakunta, työyhteisö tai luokkahuone voi samalla kertaa olla sekä kielimaisema että kieliympäristö. Kielimaisemalla viittaamme niihin konkreettisiin kieliin tai kielimuotoihin, jotka kuuluvat puhujien kielelliseen repertoaariin tai muulla tavoin ilmenevät yhteisöissä tai alueellisesti. Kieliympäristöllä viittaamme kielimaiseman funktionaalisempaan puoleen eli siihen, millaista kielimaisemassa on elää ja toimia. Kieliympäristöön liittyy itse kielten ohella mm. eri kielimuotojen ja niiden puhujien juridinen ja sosiaalinen asema sekä mahdollisuudet osallistua yhteisön toimintaan ja kieliympäristön kehittämiseen.

Kielellistä hyvinvointia edistävien ympäristöjen syntymistä ja säilymistä voidaan tukea kielipolitiikalla ja koulutuksella (Skutnabb-Kangas ym. 2009; Skutnabb-Kangas 2012b). Kielipoliittinen pyrkimys edistää kielellistä hyvinvointia näkyy Suomessa sekä peruskoulun että lukion viimeisimmissä opetussuunnitelman perusteissa, joissa tuodaan selvästi esille monikielisyyden merkitys osana nykyistä tasa-arvoista yhteiskuntaa (Opetushallitus 2014, 2015). Kummankin opetussuunnitelman mukaan koulutuksen tavoitteena on ohjata koululaisia "arvostamaan eri kieliä ja kulttuureja sekä edistää kaksi- ja monikielisyyttä ja siten vahvistaa opiskelijoiden kielellistä tietoisuutta ja metakielellisiä taitoja" (Opetushallitus 2014: 86; Opetushallitus 2015: 28). Sama muotoilu näyttäisi säilyvän jatkossakin, sillä se löytyy myös valmisteilla olevan lukion opetussuunnitelman perusteiden luonnoksesta (Opetushallitus 2019: 27). Erillisinä ryhminä näissä kaikissa mainitaan Suomen perustuslain 17 § mukaisesti saamenkieliset, romanikieliset ja viittomakieliset sekä näiden lisäksi vielä muut monikieliset tai vieraskieliset oppilaat, joiden osalta tunnustetaan oman kielen käytön tärkeys identiteetin rakentumisen ja itsetunnon kannalta. 
Juuri itsetunnon kautta yhteisön kielellinen hyvinvointi kytkeytyy läheisesti yksilön kielelliseen hyvinvointiin, sillä yhteisössä syrjään tai vähemmistöön jäävien kieliryhmien edustajat kokevat tyypillisesti valtakielen puhujia enemmän huonoa itsetuntoa ja jopa köyhyyttä, joka saattaa edelleen johtaa masennukseen, kuten Kunnas (2003: 415) toteaa. Tästä esimerkiksi käyvät saamenkielisten nuorten käyttäytymisongelmat Norjassa (Kvernmo \& Heyerdahl 1998) tai Ruotsista Suomeen paluumuuttaneiden lasten ja nuorten henkiset ongelmat (Vuorenkoski 2000), joilla on selvä yhteys kieliympäristöön ja sen ongelmiin. Kaiken kaikkiaan oman kielen käytöllä ja arvostuksella on siis vahva yhteys ihmisen identiteettiin ja tätä kautta henkiseen hyvinvointiin.

Merkittävä tekijä yksilön kielellisen hyvinvoinnin kannalta on mahdollisuus kasvaa ja elää terveessä ja monimuotoisessa kieliympäristössä - tai Bakin ja Mehmedbegovicin (2017) metaforaa käyttääksemme - mahdollisuus noudattaa terveellistä kieliruokavaliota. Metsä, niitty, ranta tai jopa viljelmä, jonka lajikirjo on monipuolinen, on elinympäristönä vastustuskykyisempi, terveempi ja pitkäikäisempi kuin monotyyppinen viljelmä, joka köyhdyttää maaperää ja on altis tuholaisten ja kasvitautien hyökkäyksille (ks. esim. Nettle \& Romaine 2000: 268-270). Samaan tapaan kielellisesti monimuotoisessa yhteisössä voi olla terveellisempää ja ehkä myös kiinnostavampaa ja miellyttävämpää elää kuin puhtaaksiviljellyssä yksikielisessä ympäristössä (ks. Nettle \& Romaine 2000: 284, 287, 290, 293). Yhteisö, jossa kaikkia kieliä arvostetaan ja kaikkien kielten puhujien oikeuksista huolehditaan, pystyy todennäköisesti vastustamaan suvaitsemattomuutta, sortoa ja erilaisia ääriliikkeitä tehokkaammin kuin kielellinen ja kulttuurinen monotypia (ks. esim. Baker 2006; Skutnabb-Kangas 2012b; Piller 2016; Chibaka 2018). Altistuminen monikielisyydelle ja kielelliselle variaatiolle tarjoaa yhteisön jäsenille kognitiivista haastetta ja harjoitusta samaan tapaan kuin monipuolinen ruokavalio ja liikunta antavat aineksia terveyteen, vastustuskykyyn ja hyvän kunnon ylläpitämiseen (ks. esim. Kharkhurin 2012). 


\section{AFinLAn vuosikirjan 2019 artikkelit}

Vuosikirjan vertaisarvioiduista artikkeleista ensimmäinen on symposiumin kutsupuhujan, Tove Bullin, historiallinen katsaus Norjan kansalliseen kielimaisemaan ja sen muotoutumiseen nykyisen kaltaiseksi. Norjahan on tunnettu kahdesta kirjakielestään - Bokmål ja Nynorsk - joilla kummallakin on virallinen ja lain turvaama asema. Nykytilanne on tulos monivaiheisesta historiallisesta kehityksestä, jossa osansa on ollut paitsi yksittäisten kansalaisten työpanoksella ja tietoisella kielipolitiikalla myös sattuman oikuilla: missään vaiheessa kahta kirjakieltä ei erityisesti tavoiteltu. Vuosina 1917-1959 pyrittiin jopa tuomaan Bokmål ja Nynorsk lähemmäksi toisiaan, jotta syntyisi Samnorsk, kaikille norjalaisille yhteinen kirjakieli (ks. Bull 2011). Tästä hankkeesta kuitenkin luovuttiin vähitellen, eikä edelleenkään ole täysin selvää, miksi näin kävi. Lopputuloksena Norjaan syntyi kuitenkin omalaatuinen kielimaisema: kaksi virallista kirjakieltä, joissa kummassakin on enemmän variaatiota kuin mitä standardikielissä tavallisesti sallitaan. Lisäksi murteilla on korkea prestiisi puhutussa kielessä. Kaikki Norjassa asuvat ja norjan kieltä opiskelevat ja käyttävät altistuvat siis suurelle määrälle variaatiota. Bull ei artikkelissaan ota kantaa siihen, voidaanko tätä pitää yksiselitteisesti myönteisenä tai kielteisenä asiana. Hänen mukaansa useat tutkimukset viittaavat kuitenkin siihen, että variaatiolle altistuminen voi parantaa puhujien kognitiivisia taitoja ja siten edistää heidän kielellistä hyvinvointiaan: norjalaiset itse ymmärtävät yleensä paremmin tanskaa ja ruotsia kuin ruotsalaiset ja tanskalaiset ymmärtävät norjaa (ks. esim. Haugen 1972; Maurud 1976; Delsing \& Lundin-Åkesson 2005). Myös norjaa opiskelleiden maahanmuuttajien on todettu ymmärtävän paremmin ruotsia ja tanskaa kuin näitä kieliä opiskelleet maahanmuuttajat ymmärtävät norjaa. (Delsing \& Lundin-Åkesson 2005.)

Norjan kielimaisemaan sijoittuu myös Leena Niirasen artikkeli kveenien omakielisen lukemisen traditiosta ja sen merkityksestä kielen säilymiselle. PohjoisNorjan suomalaismurteiden eli kveenin kielen juuret ovat 1500-luvulta lähtien Norjaan muuttaneiden pohjoissuomalaisten murteissa. Nykyisellä kveenin kielellä on ollut Norjassa vuodesta 2005 virallisen vähemmistökielen asema, mutta niin kielen käyttäjien kuin tutkijoidenkin näkemykset vaihtelevat sen suhteen, onko kielimuoto edelleen osa suomen kielen Peräpohjolan murteita vai oma itsenäinen kielensä. Yhtä kaikki kveeniä on voinut opiskella Tromssan yliopistossa vuodesta 2006, ja kveenin kielen kielioppi julkaistiin vuonna 2014.

Artikkelissaan Niiranen esittelee kveeniasutuksen synnyn Pohjois-Norjaan ja sen leviämisen 1800-luvulla. Niiranen tarkastelee kveeniväestön omakielistä lukuja kirjoitustaitoa ja heidän käytössään ollutta omakielistä kirjallisuutta. Artikkeli esittelee kveenien lukemaa kirjallisuutta lähtien ensimmäisistä alueelle tuoduista suomenkielisistä kirjoista, joista valtaosa edustaa uskonnollista kirjallisuutta. Uskonnollisen kirjallisuuden lisäksi artikkelissa tarkastellaan kveenien lukemaa 
maallista kirjallisuutta ja sanomalehtiä sekä kaksikielisiä oppikirjoja, joiden avulla omaa kieltä opittiin lukemaan. Uskonnollisen ja maallisen kirjallisuuden lukemista tarkastellaan lukemisen kulttuurin näkökulmasta. Kveenin puhujien lukutaidolla ja lukuharrastuksella on ollut merkittävä rooli kielen säilymisen kannalta. Lukuharrastus ja kirjallisen tradition olemassaolo on tarjonnut myös pohjan kirjakielelle, jota alettiin kehittää 2000-luvulla. Niiranen nostaa kuitenkin esiin myös kveenien kaksikielistymisen, joka on vaikuttanut omakielisen lukemisen ja ylipäätään oman kielen käytön vähentymiseen.

Kielelliseen hyvinvointiin kuuluu myös kielellisesti monimuotoinen koulu, jossa opiskelijan äidinkielen asema on turvattu ja jossa on mahdollisuus opiskella vieraita kieliä monipuolisesti. Suomessa laki ja opetussuunnitelmat takaavat kaikille oikeuden opiskella paitsi suomea ja ruotsia myös vieraita kieliä ja opiskelijoiden omia äidinkieliä. Uusimmissa perusopetuksen opetussuunnitelman perusteissa (Opetushallitus 2014) monikielisyys ja opiskelijoiden omat äidinkielet esitetään ongelman sijaan resurssina. Vaatii kuitenkin vielä paljon työtä, jotta suomalaisesta koulusta saataisiin ympäristö, joka aidosti edistää opiskelijoiden kielellistä hyvinvointia. Salla-Maria Suurniemi on tutkinut Helsingin koulukohtaisia opetussuunnitelmia diskurssianalyysin keinoin ja verrannut niissä ilmeneviä kielikäsityksiä ja kieli-ideologioita perusopetuksen opetussuunnitelman perusteiden vastaavaan diskurssiin. Suurniemi toteaa artikkelissaan, etteivät yhteisen opetussuunnitelman käsitykset ole vielä siirtyneet koulukohtaisten opetussuunnitelmien teksteihin vaan useat koulukohtaiset opetussuunnitelmat rakentavat yksikielisyyden diskurssia. Usein monikieliset oppilaat määritellään kielitaidoltaan heikoiksi tai heidän monikielinen repertoaarinsa sivuutetaan, vaikka se voisi olla resurssi kouluyhteisölle.

Monikielisessä ympäristössä toteutettua suomen opetusta tarkastelee puolestaan Tatsiana Shestunova, jonka artikkeli perustuu maahanmuuttajille suunnatun valmistavan koulutuksen parissa toimivien opettajien haastatteluihin. Shestunovan tutkimuksessa käy ilmi, että valmistavan opetuksen käytännöissä näkyvät niin yksikielisyyden, kaksikielisyyden kuin monikielisyydenkin normit. Tutkimukseen osallistuneet opettajat, joista lähes kaikilla oli aiempaa kokemusta monikielisistä ympäristöistä, suhtautuvat ei-suomenkielisten koululaisten ensikieliin periaatteessa myönteisesti ja kannattavat monikielisyyttä. Käytännön luokkatilanteissa he kuitenkin rajoittavat muiden kielten käyttöä, sillä he eivät hahmota oppilaan äidinkieltä tai tämän kotona puhuttavia kieliä kielenoppimisen resurssina, vaan näkevät ns. kotikielen käytön hankaloittavan suomen oppimista. Toisaalta suomen käyttöä perustellaan myös sillä, että näin estetään kiusaamista, jota hallitsevan vähemmistökielen käyttö luokassa voisi aiheuttaa. Asiantuntemuksensa osalta valmistavan opetuksen opettajat kokevat kaipaavansa lisäkoulutusta sekä erityispedagogiikasta että suomen opettamisesta toisena tai vieraana kielenä, joihin liittyvä tieto auttaisi heitä paremmin huomioimaan oppilaiden henkilökohtaiset 
tarpeet. Jatkossa onkin tärkeää lisätä tietoutta ja myönteistä asennetta monikielisyyttä kohtaan, sillä monikielisyyden rooli resurssina ja identiteetin vahvistajana on tunnistettu myös uusien opetussuunnitelmien perusteissa. Shestunovan mukaan tulevaisuudessa olisikin tärkeää tutkia, miten asia toteutuu käytännössä.

Karoliina Inhan ja Ari Huhdan artikkeli sijoittuu niin ikään koulumaailmaan. Heidän tutkimuksessaan tarkastellaan varhennetun kielenopetuksen vaikutusta opiskelijoiden asenteisiin englannin kieltä ja sen opiskelua kohtaan ja punnitaan varhennetun kielenopetuksen hyötyjä. Kohteena ovat peruskoulun 1.-3.-luokkien oppilaat, joista kukin ryhmä on opiskellut englantia yhtä pitkään, puoli vuotta, ennen tutkimukseen osallistumista. Ryhmiä vertaillaan määrällisin menetelmin taustakyselyn, itsearvioinnin ja oppimistehtävien avulla. Ajankohtaiseksi aiheen tekee se, että kieltenopetusta Suomessa varhennetaan vuoden 2020 alusta, jonka jälkeen jokainen aloittaa kieltenopiskelun jo ensimmäisenä kouluvuonna. Inhan ja Huhdan tulokset tukevat pitkälti aiemmin havaittua. Englannin kieleen ja sen opiskeluun suhtaudutaan hyvin myönteisesti ikäryhmästä riippumatta. Sen sijaan osaamisen taso on sekä itsearvioinnin että oppimistehtävien perusteella sitä parempi, mitä vanhempia koululaiset ovat, joten kielitaitoon varhaisella aloituksella ei näyttäisi olevan suurta vaikutusta. Osaltaan tämä selittyy kognitiivisten kykyjen kehityksellä. Englannin käyttö koulun ulkopuolella on 3.-luokkalaisilla merkitsevästi monipuolisempaa kuin 1.- ja 2.-Iuokkalaisilla, minkä voisi odottaa vaikuttavan myös opiskelumotivaatioon myönteisesti, kuten Inha ja Huhta toteavat. Kokonaisuudessaan kielitaito, motivaatio, vapaa-ajan kielenkäyttö ja kognitiiviset kyvyt kietoutuvat toisiinsa moniulotteisella tavalla, joka kaipaa lisäanalyysia. Inhan ja Huhdan tutkimus tarjoaakin pohjan pitkittäistutkimukselle, jossa ilmiöiden kimppua on tarkoitus tarkastella myös laajemmasta kielikasvatuksen näkökulmasta.

Monimuotoiseen kielimaisemaan kuuluvat myös erityisalojen kielet, joihin puolestaan kuuluvat termit (ks. esim. Nuopponen 2003, 2008). Termien selittäminen ja avaaminen on tapa huolehtia siitä, etteivät kieliyhteisön jäsenet jää ulkopuolisiksi vaan pääsevät osallisiksi erityisalojen diskurssista. Henri Satokankaan artikkeli käsittelee termien selittämistä yleistajuisen tietokirjallisuuden multimodaalisessa diskurssissa, jonka elementteihin kuuluvat tekstin lisäksi kuvat ja kaaviot sekä eri elementtien yhteisvaikutus. Satokangas havainnollistaa kahdella esimerkkitapauksella, kuinka multimodaalisia termiselitystä voidaan analysoida käyttämällä apuna ns. toimintokuviota, jossa kuvan ja sanan muodostamaa kokonaisuutta tarkastellaan niihin kytkeytyvän toiminnan kautta. Näin eri modaliteetit voidaan yhdistää, eivätkä ne jää toisistaan irrallisiksi, kuten perinteisessä systeemis-funktionalistisessa analyysissa (esim. Halliday 1973) helposti käy. Satokankaan mukaan luonnontieteellisen tietokirjatekstin terminselitys toteuttaa toimintokuviota ESITTELY-KUVAUS, jossa kuva ja teksti esittävät rinnakkain samaa tietoa. Ihmistieteiden alaan kuuluvassa tapauksessa kuva taas toimii yksittäisenä, 
termiä havainnollistavana esimerkkinä ja täydentää näin tekstin käsitteelliseltä tasolta yksittäisiin tapauksiin etenevää selitystä. Tällöin toimintokuviona on ESITTELY-ESIMERKKI. Lisätutkimus aiheesta on tarpeen, mutta tuloksista voidaan odottaa olevan hyötyä esimerkiksi tieteen popularisoijia tai oppikirjojen tekijöitä koulutettaessa.

Termien selittämisellä kuvan ja sanan keinoin on tekstilajina pitkät perinteet. Monimuotoiseen kielelliseen ympäristöön syntyy kuitenkin myös uusia multimodaalisia diskursseja sekä uusia tapoja osallistua niihin ja käyttää kieltä. Internetin myötä ovat syntyneet $\mathrm{mm}$. blogitekstit, Facebook-päivitykset sekä Instagramin hashtagit, joista viimeksi mainittuja Jutta Rosenbergin artikkeli käsittelee. Aikaisemmat tutkimukset (ks. esim. Scott 2015; Wikström 2014; Zappavigna 2011, 2018) ovat osoittaneet, että hashtageillakin on oma kielioppinsa. Erityisen relevantiksi hashtagien tutkimuksessa ovat osoittautuneet systeemis-funktionaalinen kieliteoria (ks. esim Halliday 1973, 1978) sekä Sperberin ja Wilsonin (1986) relevanssiteoriaa soveltava Scottin (2015) pragmaattinen analyysimalli. Näiden pohjalta Rosenberg on rakentanut oman mallinsa erityisesti suomenkielisten hashtagien analysoimiseksi. Hänen mukaansa suomenkielisten Instagram-päivittäjien hashtagit toimivat ainakin kolmessa eri roolissa: avainsanoina, kontekstin rakentajina ja evaluatiivisina metakommentteina. Kussakin roolissa hashtag joko korostaa päivityksen teemaa, antaa päivitykseen liittyen lisää informaatiota tai arvioi päivityksen sisältöä. Kaiken lisäksi samalla hashtagilla voi olla useampi eri rooli. Rosenbergin tutkimus on ensimmäisiä, joissa tarkastellaan laajan aineiston avulla suomenkielisten hashtagien käyttöä. Suomenkielisten hashtagien perusfunktiot vastaavat aiemmin tutkittujen englanninkielisten hashtagien käyttöä, mutta tutkimus avaa myös uusia näkökulmia juuri suomenkielisten hashtagien ja niiden kieliopillisten funktioiden erityispiirteisiin.

Artikkelikokoelman päättää Päivi Kuusen puheenvuoro kääntäjäkoulutuksen merkityksestä vähemmistökielille ja niiden säilymiselle. Kääntäminen on Kuusen mukaan aina kielipoliittinen teko, mutta sen yhteiskunnallinen merkitys riippuu paljon siitä, käännetäänkö enemmistö- vai vähemmistökielille. Kääntämisen päätarkoitus on viestintä eri kieli- ja kulttuuriryhmien välillä. Kannattaako vähemmistökielille siis kääntää, kun niiden puhujat yleensä osaavat myös yhteiskunnan enemmistökieltä ja pystyvät viestimään sen avulla? Tutkimusten mukaan (ks. esim. Toury 1985; Tymoczko 2006) kääntämisen merkitys vähemmistökielille on kuitenkin suuri: kääntäminen kehittää vähemmistökieliä, valloittaa niille uusia käyttöaloja ja parantaa niiden näkyvyyttä yhteiskunnassa. Koska käännökset syntyvät alkuperäisteoksia nopeammin, kääntämällä voidaan myös lisätä tehokkaasti oppimateriaalien ja muiden vähemmistökielille tarpeellisten kielituotteiden määrää (ks. Sarhimaa 2016: 269-270).

Kääntäjänkoulutus on yleensä suunnattu tuleville kääntämisen ammattilaisille, mutta vähemmistökielen kääntämisellä ei sen pienen volyymin vuoksi voi ansaita elantoa. Kiännä-hankkeen järjestämää kääntäjäkoulutusta ei 
siis suoraan voi rinnastaa esim. yliopistojen kääntäjäkoulutusohjelmiin. Kuusen esittelemässä Kiännä-hankkeessa kääntäjänkoulutusta tarjottiin Suomessa ja Venäjällä asuville karjalan puhujille. Koulutukseen olivat tervetulleita kaikkien karjalan kielen varieteettien puhujat, taitotasosta riippumatta. Opiskelijoita pyrittiin voimaannuttamaan oman kielensä tuntijoina ja käyttäjinä. Erityisesti haluttiin tukea kieliaktivisteja, jotka joutuvat usein kääntämään vähemmistökielille ilman minkäänlaista kääntäjänkoulutusta. Seminaarin työtapoihin kuului paitsi tekstien kääntäminen myös termien ja muiden uudissanojen muodostaminen sekä siihen liittyvä tiedonhaku. Metakognitiivisia taitojaan opiskelijat kehittivät kirjoittamalla käännöskommentteja, joissa oma käännösprosessi kuvattiin vaihe vaiheelta.

Vähemmistökielille kääntäminen on käännöstyötä vaikeutetuissa olosuhteissa (Kuusi 2017). Työskentelyn tekevät haasteelliseksi kohdekielen sanastolliset aukot sekä rinnakkaistekstien puute. Lisäksi kääntäminen voi helposti altistaa vähemmistökielen laajamittaiselle enemmistökielen vaikutukselle eli interferenssille (Toury 1985: 6-8; Cronin 2003: 146-147; Kuusi 2017: 50-57). Lähdeja kohdekielen erillään pitäminen kuuluukin kääntäjien perustaitoihin. Erityisen tärkeää interferenssin kontrolloiminen on kuitenkin silloin, kun käännetään vähemmistökielille. Niille luonteenomaisen ilmaisutavan vaaliminen onkin Kuusen puheenvuoron mukaan kääntäjänkoulutuksen tärkeimpiä anteja vähemmistökielten elvytykselle. 


\section{Lähteet}

Antoniou, K., K. Grohmann, M. Kambanaros \& N. Katsos 2016. The effect of childhood bilectalism and multilingualism on executive control. Cognition 149, 18-30. https:// doi.org/10.1016/j.cognition.2015.12.002.

Bak, T., \& D. Mehmedbegovic 2017. Healthy linguistic diet: the value of linguistic diversity and language learning across the lifespan. Languages, Society \& Policy, 1-9. https:// doi.org/10.17863/CAM.9854.

Baker, C. 2006. Foundations of bilingual education and bilingualism. 4th edition. Clevedon: Multilingual Matters.

Bull, T. 2011. Samnorsk. In J. A. Fishman \& O. Garcia (eds) Handbook of language and ethnic identity: Vol. 2, the success-failure continuum in language and ethnic-identity efforts. New York: Oxford University Press, 432-444.

Calvet, L. 2006. Towards an ecology of world languages. Cambridge: Polity.

Cronin, M. 2003. Translation and globalization. London/New York: Routledge.

Cruz-Ferreira, M. 2006. Three is a crowd? Acquiring Portuguese in a trilingual environment. Clevedon: Multilingual Matters.

Cenoz, J. \& D. Gorter 2006. Linguistic landscape and minority languages. In D. Gorter (eds) Linguistic landscape: a new approach to multilingualism. Clevedon: Multilingual Matters, 67-80.

Chibaka, E. F. 2018. Advantages of bilingualism and multilingualism: multidimensional research findings. Teoksessa S. B. Chumbow (toim.) Multilingualism and bilingualism. London: IntechOpen, 15-36. https://www.intechopen.com/books/ multilingualism-and-bilingualism/advantages-of-bilingualism-and-multilingualismmultidimensional-research-findings.

Delsing, L. \& K. Lundin-Åkesson 2005. Håller språket i hop i Norden? En forskningsrapport om ungdomars förståelse av dansk, svenska och norska. København: Tema Nord.

Dufva, H. \& S. Pietikäinen 2009. Moni-ilmeinen monikielisyys. Puhe ja kieli, 29 (1), 1-14. https://journal.fi/pk/article/view/4789.

Fleisch, A. 2018. Colonial legacies and linguistic repertoires in European Amazigh. In Y. Aixelà Cabré (ed.) In the footsteps of Spanish colonialism in Morocco and Equatorial Guinea: the handling of cultural diversity and the socio-political influence of transnational migration. Berlin: LIT Verlag Münster, 185-207.

Gorter, D. 2006. Introduction: the study of the linguistic landscape as a new approach to multilingualism. In D. Gorter (ed.) Linguistic landscape: a new approach to multilingualism. Clevedon: Multilingual Matters, 1-6.

Gorter, D., G. Hogan-Brun, H. F. Marten \& L. Van Mensel (eds) 2012. Minority languages in the linguistic landscape. Basingstoke: Palgrave Macmillan.

Halliday, M. A. K. 1973. Explorations in the functions of language. London: Edward Arnold.

Halliday, M. A. K. 1978. Language as social semiotic: the social interpretation of language and meaning. Baltimore: University Park Press.

Haugen, E. 1972. Semicommunication: The language gap in Scandinavian. In E. Firchow (ed.) Studies by Einar Haugen: presented on the occasion of his 65th birthday, April 19, 1971. Janua Linguarum. Series Maior 49. Berlin: Mouton de Gruyter, 479-495.

Himmele, P. \& W. Himmele 2009. The language-rich classroom: a research-based framework for English language learners. Alexandria, VA: Association for Supervision and Curriculum Development.

Ivkovic, D. \& H. Lotherington 2009. Multilingualism in cyberspace: conceptualizing the virtual linguistic landscape. International Journal of Multilingualism, 6 (1), 17-36. https://doi. org/ 10.1080/14790710802582436. 
Kharkhurin, A. V. 2012. Multilingualism and creativity. Bristol: Multilingual Matters.

Kolehmainen, L., K. Koskinen \& H. Riionheimo 2015. Arjen näkymätön kääntäminen: translatorisen toiminnan jatkumot. Virittäjä, 119 (3), 372-400. https://journal.fi/ virittaja/article/view/48307.

Kolehmainen, L., E. Penttilä \& P. Van Poucke (toim.) 2016. Special issue: current issues in the linguistic analysis of literary translation. International Journal of Literary Linguistics, 5 (3). https://journals.linguistik.de/ijll/issue/view/10.

Kotus 2015-2018. Toiminta- ja taloussuunnitelma 2015-2018. Helsinki: Kotimaisten kielten keskus. https://www.kotus.fi/files/2558/tts2015-2018.pdf [luettu 25.11.2019].

Kreslins, J. 2003. Linguistic landscapes in the Baltic. Scandinavian Journal of History, 28 , 165-174. https://doi.org/10.1080/03468750310003659.

Kunnas, N. 2003. Revitalization of minority languages as a way to promote well-being in the north. International Journals of Circumpolar Health 62 (4), 410-422. https://doi. org/10.3402/ijch.v62i4.17584.

Kuusi, P. 2017. Varovasti, haurasta! Vähemmistökielet ja kääntäjänkoulutus. MikaEL: kääntämisen ja tulkkauksen tutkimuksen symposiumin verkkojulkaisu, 10, 47-59. https://helda.helsinki.fi//bitstream/handle/10138/241953/Mikael_vol.10. pdf? sequence $=1$.

Kuusi, P., L. Kolehmainen \& H. Riionheimo 2017. Introduction. Multiple roles of translation in the context of minority languages and revitalization. Trans-kom: Journal of translation and technical communication, 10 (2), 138-163. http://www.trans-kom.eu/bd10nr02/ trans-kom_10_02_02_Kuusi_Kolehmainen_Riionheimo_Introduction.20171206.pdf.

Kvernmo, S. \& S. Heyerdahl 1998. Influence of ethnic factors on behavior problems in indigenous Sami and majority Norwegian adolescents. Journal of the American Academy of Child \& Adolescent Psychiatry, 37 (7), 743-751. https://doi. org/10.1097/00004583-199807000-00014.

Landry, R \& R. Y. Bourhis 1997. Linguistic landscape and ethnolinguistic vitality. Journal of Language and Social Psychology, 9 (1), 23-49. https://doi. org/10.1177/0261927X970161002.

Lindeman, M., C. Lindholm, M. Luodonpää-Manni \& J. Paananen (toim.) tulossa. Kieli, hyvinvointi ja sosiaalinen osallisuus.

Lindgren, A.-R. 2001. Oikeus omaan kieleen. Virittäjä, 105 (2), 239-255. https://journal.fi/ virittaja/article/view/40084.

Lindholm, C. \& C. Wide 2019a. Formelartade och mer schematiska konstruktioner hos personer med demens. I M. Bianchi, D. Håkansson, B. Melander, L. Pfister, M. Westman \& C. Östman (red.) Svenskans beskrivning 36. Förhandlingar vid trettio-sjätte sammankomsten. Uppsala 25-27 oktober 2017. Uppsala: Institutionen för nordiska språk vid Uppsala universitet, 143-154. http://www.diva-portal.org/smash/record. jsf?pid=diva2\%3A1313414\&dswid=9830.

Lindholm, C. \& C. Wide 2019b. Self-directed speech and dialogue in dementia care: the potential of co-participants' contributions. Logopedics Phoniatrics Vocology 44 (1), 14-22. https://doi.org/10.1080/14015439.2019.1554853.

Luodonpää-Manni, M. \& J. Paananen 2018. Kielen ja hyvinvoinnin tutkimuskeskus LaWe lisää tietoa kielen ja hyvinvoinnin välisistä yhteyksistä. Hiiskuttua: Turun yliopiston humanistisen tiedekunnan verkkojulkaisu. https://sites.utu.fi/hiiskuttua/kielen-jahyvinvoinnin-tutkimuskeskus-lawe-lisaa-tietoa-kielen-ja-hyvinvoinnin-valisistayhteyksista/.

Maurud, Ø. 1976. Nabospråksforståelse i Skandinavia. Stockholm: Nordiska rådet.

Meijaard, E., J. Garcia-Ulloa, D. Sheil, S.A.Wich, K.M. Carlson, D. Juffe-Bignoli, M. Brooks, T.M. 
(eds) 2018. Oil palm and biodiversity: a situation analysis by the IUCN Oil Palm Task Force. Gland, Switzerland: IUCN. https://doi.org/10.2305/IUCN.CH.2018.11.en.

Moshnikov, I. 2016. Karjalankieliset verkkosivut virtuaalisena kielimaisemana. Lähivõrdlusi. Lähivertailuja, 26, 282-310. https://doi.org/10.5128/LV26.09.

Nettle, D. \& S. Romaine 2000. Vanishing voices: the extinction of the world's languages. New York: Oxford University Press.

Novak, l., M. Penttonen, A. Ruuskanen, \& L. Siilin 2019. Karjala kieliopeissa. Fonetiikan ja morfologian vertaileva tutkimus. Petroskoi: KNC RAN.

Nuopponen, A. 2003. Käsiteanalyysi asiantuntijan työvälineenä. Kieli ja asiantuntijuus. AFinLA-vuosikirja 2003 (Suomen soveltavan kielitieteen yhdistyksen julkaisuja 61). Jyväskylä: Suomen soveltavan kielitieteen yhdistys AFinLA, 13-24. https://journal.fi/ afinlavk/issue/view/4206.

Nuopponen, A. 2008. Etsi, käytä, vaikuta ja osallistu - sanalistoista verkkoyhteistyöhön. Terminfo 2008, 29 (2), 12-14. http://www.terminfo.fi/sisalto/terminfo-22008-399.html.

Opetushallitus 2014. Perusopetuksen opetussuunnitelman perusteet 2014. Helsinki: Opetushallitus. http://www.oph.fi/download/163777_perusopetuksen_ opetussuunnitelman_perusteet_2014.pdf.

Opetushallitus 2015. Lukion opetussuunnitelman perusteet 2015. http://www.oph.fi/ download/172124_lukion_opetussuunnitelman_perusteet_2015.pdf.

Opetushallitus 2019. Lukion opetussuunnitelman perusteiden luonnos 2019. https://www. oph.fi/sites/default/files/documents/lukion_opetussuunnitelman_perusteiden_ luonnos_14032019_1.pdf.

Paananen, J. 2018. Päätöksentekokeskustelu monikulttuurisilla lääkärin vastaanotoilla. Sosiaali-lääketieteellinen Aikakauslehti 55 (4), 287-308. https://doi.org/10.23990/ sa.66980.

Paananen, J. 2019. Yhteisymmärryksen rakentaminen monikulttuurisilla lääkärin vastaanotoilla. Turun yliopiston julkaisuja C 465, Turun yliopisto. http://urn.fi/ URN:ISBN:978-951-29-7557-0.

Paananen, J. \& A. R. Majlesi 2018. Patient-centered interaction in interpreted primary care consultations. Journal of Pragmatics 138, 98-118. https://doi.org/10.1016/j. pragma.2018.10.003.

Paulasto, H. 2018. Taide ja kielellinen hyvinvointi - qué? TuMaTa - Tutkiva ja mahdollistava taide -hanke. https://tumatablog.wordpress.com/2018/10/07/taide-ja-kielellinenhyvinvointi-que/ [luettu 25.11.2019].

Paulasto, H., L. Meriläinen, H. Riionheimo \& M. Kok (eds) 2014. Language contacts at the crossroads of disciplines. Newcastle upon Tyne: Cambridge Scholars Publishing.

Phillipson, R. 2012. Linguistic imperialism. In C. A. Chapelle (ed.) The encyclopedia of applied linguistics. Wiley Online Library. Hoboken: Blackwell Publishing, 1-7. https://doi. org/10.1002/9781405198431.wbeal0718.

Phillipson, R. \& T. Skutnabb-Kangas 2013. English, Language Dominance, and Ecolinguistic Diversity Maintenance. In M. Filppula, J. Klemola \& D. Sharma (eds) The Oxford handbook of world Englishes. New York: Oxford University Press. htpps://doi.org/ 10.1093/oxfordhb/9780199777716.013.005.

Piller, I. 2016. Linguistic diversity and social justice: an introduction to applied sociolinguistics. Oxford: Oxford University Press.

Pyykkö, R. 2017. Monikielisyys vahvuudeksi. Selvitys Suomen kielivarannon tilasta ja tasosta. Opetus- ja kulttuuriministeriön julkaisuja 2017:51. Helsinki: Opetus- ja kulttuuriministeriö. http://urn.fi/URN:ISBN:978-952-263-535-8.

Riionheimo, H. 2015. Multiple roots of innovations in language contact: evidence from morphological intermingling in contact between Ingrian Finnish and Estonian. In 
H. De Smet, L. Ghesquière \& F. Van de Velde (eds) On multiple source constructions in language change. Amsterdam: John Benjamins, 175-204.

Riionheimo, H. \& M. Frick 2013. Bilingual voicing: a study of code-switching in the reported speech of Finnish immigrants in Estonia. Multilingua, 32 (5), 565-599. https://doi. org/0.1515/multi-2013-0028.

Riionheimo, H., L. Kolehmainen, M. Kumpulainen, L. Meriläinen, P. Muikku-Werner \& E. Penttilä 2014. Kontaktilingvistiikan, toisen kielen omaksumisen tutkimuksen ja käännöstieteen risteyksessä. Virittäjä, 118 (3), 317-333. https://journal.fi/virittaja/ article/view/45338.

Sarhimaa, A. 2017. Vaietut ja vaiennetut: karjalankieliset karjalaiset Suomessa. Helsinki: Suomalaisen Kirjallisuuden Seura.

Scott, K. 2015. The pragmatics of hashtags: inference and conversational style on Twitter. Journal of Pragmatics, 81, 8-20. https://doi.org/10.1016/j.pragma.2015.03.015.

Shohamy, E., E. Ben-Rafael \& M. Barni (eds) 2010. Linguistic landscape in the city. Bristol: Multilingual Matters.

Skutnabb-Kangas, T. 2000. Linguistic genocide in education - or worldwide diversity and human rights? New York: Routledge.

Skutnabb-Kangas, T. 2012a. Linguistic human rights. In P. A. Tiersma \& L. M Solan (eds) The Oxford handbook of language and law. Oxford: Oxford University Press, 235-247.

Skutnabb-Kangas, T. 2012b. Role of linguistic human rights in language policy and planning. In C. A. Chapelle (ed.) The encyclopedia of applied linguistics. Wiley Online Library. Hoboken: Blackwell Publishing, 1-6. https://doi.org/10.1002/9781405198431. wbeal1026.

Skutnabb-Kangas, T., R. Phillipson, A. K. Mohanty \& M. Panda 2009. Social justice through multilingual education. Bristol: Multillingual Matters.

Sperber, D. \& D. Wilson 1986. Relevance: communication and cognition. Oxford: Blackwell.

Suomen perustuslaki 11.6.1999/731. https://www.finlex.fi/fi/laki/ ajantasa/1999/19990731\#L2P17.

Toury, G. 1985. Aspects of translating into mnority languages from the point of view of translation studies. Multilingua, 4, 3-10.

Tymoczko, M. 2006. Reconceptualizing translation theory: integrating non-western thought about translation. Teoksessa T. Hermans (toim.) Translating Others, 1. Manchester, UK/ Kinderhook, USA: St. Jerome, 13-32.

Vuorenkoski, L. 2000. Childhood between two countries: resilience and mental well-being of Finnish remigrant children and adolescents. Oulu: Oulun yliopisto. http://urn.fi/ urn:isbn:9514256018.

Wikström, P. 2014. \#srnotfunny: communicative functions of hashtags on Twitter. SKY Journal of Linguistics, 27, 127-152. http://www.linguistics.fi/julkaisut/SKY2014/Wikstrom.pdf.

WWF 2018. Grooten, M. \& R. E. A. Almond (eds) Living planet report 2018: aiming higher. Gland, Switzeland:WWF. https://c402277.ssl.cf1.rackcdn.com/publications/1187/ files/original/LPR2018_Full_Report_Spreads.pdf?1540487589.

Zappavigna, M. 2011. Ambient affiliation: a linguistic perspective on Twitter. New Media and Society, 13 (5), 788-806. https://doi.org/10.1177\%2F1461444810385097.

Zappavigna, M. 2018. Searchable talk: hashtags and social media metadiscourse. London: Bloomsbury. 